\title{
Bioavailability of Zinc in Bread Wheat Grown in the Calcareous Soils of the Kurdistan Region of IRAQ
}

Muhammed S. Rasheed ( $\square$ muhammed.rasheed@spu.edu.iq)

Sulaimani Polytechnic University https://orcid.org/0000-0002-0792-4180

\section{Scott Young}

University of Nottingham

Elezabeth Bailey

University of Nottingham

\section{Research Article}

Keywords: Zinc, phosphorus, Phytic acid, Zinc bioavailability, Bread wheat

Posted Date: March 10th, 2021

DOI: https://doi.org/10.21203/rs.3.rs-221652/v1

License: (1) This work is licensed under a Creative Commons Attribution 4.0 International License.

Read Full License 


\section{Abstract}

A survey of wheat grain from 120 fields in Sulaimanyah province, Kurdistan region, Iraq was undertaken in 2017. We evaluated the concentrations of phosphorus (P), Zn and phytic acid (PA) and the estimated $\mathrm{Zn}$ bioavailability in wheat grain grown in the calcareous soils of the region. Concentrations of $\mathrm{P}$ in wheat grain were higher than the recommended value of $3570 \mathrm{mg} \mathrm{kg}^{-1}$; PA was within the range of other countries but $\mathrm{Zn}$ concentration in $88 \%$ of wheat grain samples fell below the value recommended for human nutrition of $41.6 \mathrm{mg} \mathrm{kg}^{-1}$. Bioavailable $\mathrm{Zn}$ intake $\left(\mathrm{mg} \mathrm{d}^{-1}\right)$ was estimated assuming bread consumption of $300 \mathrm{~g} \mathrm{day}^{-1}$ in the region. Considering PA and $\mathrm{Zn}$ intake suggested only $21.5 \pm 2.9 \%$ of whole grain flour $\mathrm{Zn}$ was bioavailable. Thus the effective $\mathrm{Zn}$ intakes from whole wheat was only 1.25$2.05 \mathrm{mg} \mathrm{d}^{-1}$ for the local population. Typical dietary $\mathrm{Zn}$ was below recommended levels $\left(11 \mathrm{mg} \mathrm{d}^{-1}\right)$, due to low soil Zn uptake by wheat and the large concentrations of PA in wheat grains, probably from overuse of phosphate fertilizer.

\section{Introduction}

In calcareous soils, the bioavailability of zinc ( $\mathrm{Zn}$ ) limits crop production due to the presence of $\mathrm{CaCO}_{3}$ as an adsorbent for $\mathrm{Zn}^{2+}$ ions, high $\mathrm{pH}$ values which encourage $\mathrm{Zn}^{2+}$ adsorption on Fe oxides and humus, and the application of $\mathrm{P}$ fertilizer which may co-precipitate with $\mathrm{Zn}^{2+}$ (Duffner et al., 2012; Mousavi and Galavi, 2012; Wang et al., 2017; Wu et al., 2017). It is not clear whether Zn-P interactions occur both in the soil and in the plant (Fageria, 2001; Mousavi and Galavi, 2012). To explain the interactions between $P$ and Zn, (Fageria, 2001; Mousavi and Galavi, 2012) reported three mechanistic hypotheses including: (i) interference by $\mathrm{P}$ at the level of plant metabolism including effects on uptake, utilization and translocation of $Z n$, (ii) variation in the $P / Z n$ ratio due to changes in dry matter production with $P$ application and (iii) soil $\mathrm{P}$ and $\mathrm{Zn}$ interactions. Phosphate can also cause a decrease in the bioavailability of $\mathrm{Zn}$ within wheat grains, by decreasing the total concentration of $\mathrm{Zn}$ and increasing the molar ratio of Phytic acid (PA) to Zn (Khoshgoftarmanesh et al., 2017; Magallanes-Lopez et al., 2017).

Wheat is the main cereal crop produced in Kurdistan (Ziadi et al., 2013). Wang, (2017) reported that in many developing countries it provides about $50 \%$ of daily calorie intake. To prevent $\mathrm{Zn}$ deficiency in humans, the concentration of $\mathrm{Zn}$ in wheat grain should reach a level of around $40 \mathrm{mg} \mathrm{kg}^{-1}$ (Bouis et al., 2011; Chen et al., 2017). However, the total $Z n$ concentration of wheat grain is not the only factor controlling dietary assimilation of $\mathrm{Zn}$. The presence of 'anti-nutrient' compounds, such as PA, is one of the major considerations when evaluating the nutritional quality of crops (Poblaciones and Rengel, 2016) and the proportion of $\mathrm{Zn}$ that is readily absorbed (Magallanes-Lopez et al., 2017). To determine $\mathrm{Zn}$ bioavailability in foods, it is necessary to measure the molar ratio of PA to $\mathrm{Zn}$. A decrease in this molar ratio increases $\mathrm{Zn}$ bioavailability.

Wheat variety, growing conditions, and location are all factors that may cause differences in the bioavailability of Zn (Gabaza et al., 2018). The wheat growing area in the Kurdistan Region amounts to 
about 570,000 ha; approximately 500,000 t is harvested every year and wheat production is mostly rainfed (Mazid, 2015). Therefore, the aims of this survey were: (i) to determine the bioavailability of $P$ and $Z n$ in wheat grain; (ii) to evaluate PA concentration, the PA/Zn molar ratio and the estimated Zn bioavailability (to humans) in wheat cultivars consumed in Sulaimanyah province; (iii) to evaluate the nutrient status of wheat grain grown in the calcareous soils of Kurdistan.

\section{Materials And Methods}

\subsection{Wheat survey in Sulaimanyah province}

A total of 120 wheat grain samples were collected from fields in ten locations in Sulaimanyah province, Kurdistan region, Iraq during May-June 2017. The number of samples taken from each location was dependent on the size of a location area. Locations in selected for wheat grain sampling (Table 1) were chosen on the basis of agricultural activity (predominantly wheat production), wheat variety and geographical location. Adana and Aras are the two main wheat varieties grown in the Kurdistan region along with other varieties such as Rashidi, Barcelona, and Wafia (Table 1). In each field selected, wheat grain samples were collected from five sampling points within an area of $100 \mathrm{~m}^{2}$. The five samples were combined to produce a composite sample and sealed in plastic bags for transport to a laboratory at the Halabja Technical College of Applied Science. Wheat grain samples $(n=120)$ were collected in a Wtransect with each sample consisting of 15-20 cereal heads. Wheat heads were removed from the straw and threshed by hand to remove the outer grain husk, mixed, and a representative sample retained. Approximately $10 \mathrm{~g}$ of each sample was then stored in a plastic bag labelled and transported to the University of Nottingham, UK. A portion of each sample was finely ground using a centrifugal mill (Retsch, Model ZM200) prior to analysis. 
Table 1

Wheat varieties (five) collected at ten different locations in Sulaimanyah province.

\begin{tabular}{|llllllll|}
\hline Location & Code & No. of samples & Adana & Aras & Rashidi & Barcelona & Wafia \\
\hline Halabja & HAL & 13 & 8 & 5 & - & - & - \\
\hline Sirwan & SIR & 8 & 6 & 2 & - & - & - \\
\hline Khormal & KHO & 7 & 3 & 2 & - & 1 & 1 \\
\hline Sharazoor & SHA & 15 & 6 & 6 & - & 1 & 2 \\
\hline Said Sadiq & SSQ & 22 & 7 & 13 & - & 2 & - \\
\hline Barznja & BAR & 8 & 1 & 7 & - & - & - \\
\hline Piramagrun & PIR & 12 & 5 & 5 & - & 1 & 1 \\
\hline Chamchamal & CHA & 10 & 4 & 4 & 2 & - & - \\
\hline Darbandikhan & DAR & 10 & 3 & 6 & - & 1 & - \\
\hline Kalar & KAL & 15 & 11 & 1 & 2 & - & - \\
\hline
\end{tabular}

\subsection{Acid digestion}

Approximately $200 \mathrm{mg}$ of milled wheat grain samples were digested using microwave heating (Anton Parr, Multiwave 3000) for $45 \mathrm{~min}$ at $2 \mathrm{MPa}$ in $4.0 \mathrm{~mL} \mathrm{HNO}$ and $2.0 \mathrm{~mL} \mathrm{H}_{2} \mathrm{O}_{2}$. Digested samples were diluted to $20 \mathrm{~mL}$ with Milli-Q water and stored at room temperature prior to $\mathrm{Zn}$ analysis by ICP-MS.

\subsection{Determination of Phytic acid (PA)}

Phytic acid (PA) was determined using a Megazyme kit (K-PHYT, Megazyme, and Bray, Ireland) (Electronic appendix 1). The molar ratios of PA and $\mathrm{Zn}$ were determined by converting from gravimetric concentrations (phytate $=660.8 \mathrm{~g} \mathrm{~mol}^{-1}$ and $\mathrm{Zn}=65.38 \mathrm{~g} \mathrm{~mol}^{-1}$ ) and dividing PA concentration by $\mathrm{Zn}$ concentration.

\subsection{Determination of human $\mathrm{Zn}$ bioavailability}

Estimated human bioavailability of $\mathrm{Zn}$ was calculated for an intake of $300 \mathrm{~g}$ of grain using a published model (Eq. 3) for $Z n$ absorption as a function of dietary $Z n$ and PA. The development of the model is described in detail by Miller et al., (2007).

$\mathrm{TAZ}=0.5\left(\begin{array}{l}\mathrm{A}_{M \Delta X}+T D Z+K_{R} \times\left(1+\frac{T D P}{K_{P}}\right)- \\ \sqrt{\left(A_{M L X}+T D Z+K_{R} \times\left(1+\frac{T D P}{K_{P}}\right)\right)^{2}}-4 \times A_{M U X} \times T D Z\end{array}\right)$

Eq. 3 
Equation 3 has two predictor variables: total daily intake of $\mathrm{Zn}$ (TDZ; millimoles $\mathrm{d}^{-1}$ ) and PA (TDP) and the response variable is total absorbed $\mathrm{Zn}$ (TAZ). The model has three parameters, including maximal absorption $\left(A_{M A X}=0.091\right)$, a $Z n$-transporter binding equilibrium dissociation constant $\left(K_{R}=0.680\right)$ and a Zn-phytate binding equilibrium dissociation constant $\left(K_{P}=0.033\right)$.

\subsection{Elemental analysis}

Analysis was undertaken using ICP-MS (Thermo Fisher Scientific iCAPQ, Bremen, Germany) operated in 'collision cell mode' using helium gas to reduce polyatomic interferences. Samples were introduced from an autosampler (Cetac ASX-520). Internal standards included Ge $\left(50 \mu \mathrm{g} \mathrm{L}^{-1}\right), \mathrm{Rh}\left(10 \mu \mathrm{g} \mathrm{L}^{-1}\right)$ and $\operatorname{lr}(5 \mu \mathrm{g}$ $\left.\mathrm{L}^{-1}\right)$ in $2 \%$ Primar Plus ${ }^{\mathrm{TM}}$ grade $\mathrm{HNO}_{3}$. The $\mathrm{Zn}$ calibration standard was in the range $0-100 \mu \mathrm{g} \mathrm{L}^{-1}$ (Claritas-PPT CLMS-2, Thermo-Fisher Scientific). Measured concentrations were corrected using the average of three blank digestions and converted to $\mathrm{mg} \mathrm{kg}^{-1}$.

\subsection{Statistical analysis}

The data were analyzed using SPSS 24.0 for Windows. A one-way analysis of variance (ANOVA) followed by a least significant difference $(L S D)$ test $(p<0.05)$ was performed to test the significance of treatments. The relationships between variables were determined via Pearson's correlation analysis.

\section{Results And Discussion}

\subsection{Phosphorus and Zn concentrations in wheat grain}

At harvest, the average concentrations of $\mathrm{P}\left(\mathrm{mg} \mathrm{kg}^{-1}\right)$ in wheat grain ranged from $2890 \pm 694$ to $3630 \pm$ 490 for PIR and BAR locations respectively; there was a significant variation $(p<0.05)$ between locations (Fig. 1). About $40 \%$ of wheat grain samples contained higher concentrations than the recommended value of $3570 \mathrm{mg} \mathrm{kg}^{-1}$ of $\mathrm{P}$ (USDA Food Composition Databases, 2018), reflecting the high solubility of $\mathrm{P}$ in some of the soils probably due to the application of $\mathrm{P}$ fertilizer in each growing season by farmers. Alam and Azam Shah (2002) conducted a greenhouse experiment to study the influence of phosphate fertilization on P concentration in wheat gown in calcareous soils; they found that application of $40 \mathrm{~kg}$ $\mathrm{kg}^{-1}$ of $\mathrm{P}$ as SSP increased $\mathrm{P}$ concentration in wheat grain from 1978 to $2942 \mathrm{mg} \mathrm{kg}^{-1}$.

The average $\mathrm{Zn}$ concentration in wheat grain $\left(\mathrm{mg} \mathrm{kg}^{-1}\right)$ ranged from $26.3 \pm 7.37$ to $35.0 \pm 6.11$ for $\mathrm{CHA}$ and HAL locations respectively (Fig. 2). Similarly, Zn concentrations in bread wheat ranged from 20 to 40 $\mathrm{mg} \mathrm{kg}^{-1}$ in a study of 243 wheat genotypes cultivated in normal agricultural soils (Nikolic et al., 2016). Zhang et al. (2010) reported $29 \mathrm{mg} \mathrm{Zn} \mathrm{kg}^{-1}$ for three main wheat cultivars, grown in calcareous soils in China which did not exhibit Zn deficiency. Liu et al. (2014) analysed 655 wheat grain samples grown in the calcareous soils of China from 2009 to 2011, they found that average Zn concentrations were 30.4 and $30.3 \mathrm{mg} \mathrm{kg}^{-1}$ for winter and spring wheat respectively. Guttieri et al. (2015) analysed 286 bread wheat cultivars in the USA and observed Zn concentrations ranging from 25 to $33 \mathrm{mg} \mathrm{kg}^{-1}$. Compared to 
these extensive reports, the average value of between 26.3 to $35.0 \mathrm{mg} \mathrm{kg}^{-1}$, suggest $\mathrm{Zn}$ in wheat grain grown in Kurdistan is in the range of $\mathrm{Zn}$ concentrations reported globally for wheat grown in calcareous soils.

Approximately $88 \%$ of the surveyed wheat grain samples contained $\mathrm{Zn}$ concentrations below the value recommended for human nutrition of $41.6 \mathrm{mg} \mathrm{kg}^{-1}$ by the USDA (USDA Food Composition Databases, 2018). According to Cakmak (2008) for populations with a predominantly cereal-based diet, the $\mathrm{Zn}$ concentration in wheat grain should be as high as $40-60 \mathrm{mg} \mathrm{kg}^{-1}$ to provide an adequate level in the diet. Thus, the wheat grain grown in the calcareous soils of Kurdistan falls in the lower range of values recommended for adequate human nutrition. This situation arises because of the low availability of $\mathrm{Zn}$ in the Kurdistan soils and because farmers do not normally apply micronutrients to wheat farms in the Kurdistan region when interviewed farmers. Moreover, Nikolic et al. (2016) studied the soil Zn availability and wheat grain $\mathrm{Zn}$ status in Serbia and found that wheat grain Zn content was negatively correlated with the application of phosphate fertilizer in calcareous soils. However, in the surveyed wheat grain samples, the concentration of $\mathrm{Zn}$ was not negatively correlated with Olsen-P or with the concentration of $\mathrm{P}$ in wheat grains. This may be because farmers apply N (as Urea) along with P fertilizers (as TSP and DAP) each growing season which could offset the effect of $P$ on $Z n$ concentration in wheat grains due to the synergistic effect of applied $\mathrm{N}$ on Zn uptake by wheat plants. Akram et al. (2017) reported that nitrogenous protein has a major role in $\mathrm{Zn}$ uptake from soil to root, mobilization within the plant and accumulation. Svecnjaka et al. (2013) studied the effect of $\mathrm{N}$ fertilizer application on trace element uptake by wheat grain in a field experiment; they found that application of $194 \mathrm{~kg} \mathrm{~N}^{-1}$ as (Urea $46 \% \mathrm{~N}$ ) increased $\mathrm{Zn}$ concentration from 34.9 to $38.9 \mathrm{mg} \mathrm{kg}^{-1}$ in wheat grain. Thus, the application of $\mathrm{N}$ fertilizer alongside $\mathrm{P}$ fertilizer to wheat grown in the calcareous soils of the Kurdistan region may reduce the antagonistic effect of P on Zn uptake.

The principal reason for low concentrations of $\mathrm{Zn}$ in wheat grain is probably the presence of large concentrations of calcium carbonate in the soils and high $\mathrm{pH}$ values. These are the conditions under which Zn fixation occurs, rendering it unavailable for plant uptake (Cakmak and Kutman, 2017; Li et al., 2010). It is well documented that wheat cultivated in calcareous soils can contain relatively low concentrations of $\mathrm{Zn}$. Thus the application of a $\mathrm{Zn}$ biofortification plan could make a substantial contribution to raising the $\mathrm{Zn}$ content of wheat in Kurdistan. On the other hand, a critical Zn level of 20 to $24 \mathrm{mg} \mathrm{kg}^{-1}$ has been suggested (Nikolic et al., 2016) for rain-fed wheat grain grown on alkaline calcareous soils in Pakistan as the lowest Zn concentration in grain needed to deliver $95 \%$ of the highest grain yield (Karami et al., 2009). In the present survey, only $12 \%$ of surveyed samples had $\mathrm{Zn}$ concentrations below $24 \mathrm{mg} \mathrm{kg}^{-1}$ dry matter, suggesting that Zn deficiency to the crop may actually be a minor consideration for wheat production in the Kurdistan region, compared to the human dietary considerations.

\subsection{Phytic acid and PA/Zn molar ratio in wheat grain}




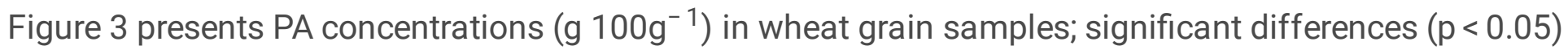
were found between the ten sampling locations. In the present survey, the average PA content in the whole wheat grains ranged from $0.54 \pm 0.16$ for HAL to $0.93 \pm 0.11$ for SSQ locations respectively. An average of $63.1 \pm 12.2 \%$ of $P$ in the wheat grain was present as PA. Results are compared with other examples in (Table 2) which shows that the Kurdistan PA concentrations fell within the range of other countries.

Table 2

Comparison of Phytic acid content in wheat grain from several countries

\begin{tabular}{|llll|}
\hline Phytic acid & Wheat & Country & References \\
\hline $\mathbf{( g} \mathbf{1 0 0 \mathbf { g } ^ { - 1 } )}$ & No. & & \\
\hline $0.42-1.12$ & 120 & Kurdistan region & Current study \\
\hline $0.46-0.95$ & 46 & Mexico & Magallanes-Lopez et al., (2017) \\
\hline $1.46-1.69$ & 15 & Serbia & Brankovic et al., (2015) \\
\hline $0.71-1.11$ & 65 & Pakistan & Hussain et al., (2012) \\
\hline $0.52-0.98$ & 186 & China & Liu et al., (2006) \\
\hline $0.60-1.00$ & 100 & Canary Islands & Febles et al., (2002) \\
\hline
\end{tabular}

The regional average PA/Zn molar ratio for whole wheat grain ranged between $15.7 \pm 5.06$ and $30.6 \pm$ 6.18 for HAL and BAR locations respectively (a 2 -fold variation) as shown in (Fig. 4); a significant difference was found between locations $(p<0.05)$. Hussain et al. (2012) and Tavajjoh et al. (2011) reported PA/Zn molar ratios ranging from 23.9 to 41.4 and 26.5 to 26.9 in 65 and 17 bread wheat and bread wheat genotypes grown in the calcareous soils of Pakistan and Iran respectively. Those PA/Zn molar ratios are broadly comparable to the current survey.

Reasons for differences in PA and PA/Zn ratios may include location, soil type, variety, climatic conditions, phosphate fertilizer application and the presence or absence of $\mathrm{Zn}$ fertilization. MagallanesLopez et al. (2017) studied PA content and PA/Zn molar ratio in a worldwide collection of commercial durum wheat and found that environmental factors caused a difference in wheat grain PA concentration

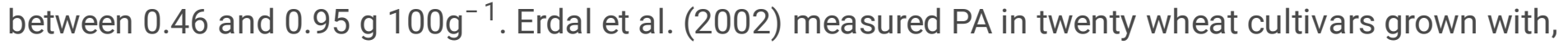
and without, Soil application of $\mathrm{Zn}$ to calcareous soils in 55 different wheat growing locations in Central Anatolia, Turkey. They reported that the application of $23 \mathrm{~kg} \mathrm{Zn} \mathrm{ha}^{-1}$ to soils reduced the PA contents of

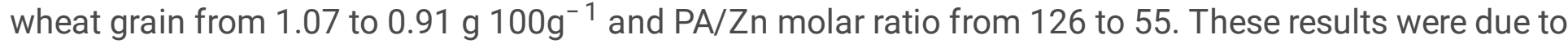
a reduction in $\mathrm{P}$ concentration in wheat grain from 3900 to $3500 \mathrm{mg} \mathrm{kg}^{-1}$ and increasing $\mathrm{Zn}$ concentration from 14 to $23 \mathrm{mg} \mathrm{kg}^{-1}$. Probably in the calcareous soils of Kurdistan, $\mathrm{P}$ deficiency occurs due to high calcium content. Therefore, when samples collected and farmers interviewed. They apply phosphate fertilizer to improve yield which causes an increase in PA content in wheat grain and in the resulting $\mathrm{PA} / \mathrm{Zn}$ ratio. 
The PA/Zn molar ratio has been used as an indicator of Zn bioaccessibility by the International Zinc Nutrition Consultative Group (IZiNCG). Considering the PA/Zn molar ratios observed in the current survey, and in previous studies on calcareous soils, it is apparent that ratios are not ideal when durum wheat is the staple food and principal source of dietary $\mathrm{Zn}$. The relatively high PA/Zn molar ratio in the current survey (average of $24.3 \pm 8.59$ ) suggests that wheat biofortification with $\mathrm{Zn}$ and decreasing the application of $\mathrm{P}$ fertilizer are urgent priorities in the Kurdistan region. Developing cereal cultivars with low PA contents and a high affinity for $Z n$ would also be useful strategies.

\subsection{Estimated Zn bioavailability in wheat grain}

Estimated $\mathrm{Zn}$ bioavailability (Eq. 3), in $\mathrm{mg} \mathrm{d}^{-1}$ assuming consumption of $300 \mathrm{~g}$ wheat per day, ranged from $1.84 \pm 0.08$ for BAR to $2.65 \pm 0.05$ for HAL locations respectively, as shown in (Table 3). A significant difference $(p<0.05)$ was found between locations. The results indicate that in all the wheat grain samples, bioavailable $\mathrm{Zn}$ is lower than the optimum level of $3 \mathrm{mg}$ from daily consumption of $300 \mathrm{~g}$ of wheat (Hussain et al., 2013) for communities dependent on wheat grain for Zn intake. Maqsood et al. (2014) estimated $\mathrm{Zn}$ bioavailability in 58 wheat cultivars grown in calcareous soils in the wheat-cotton zone of the Punjab, Pakistan, using a trivariate model. They reported that bioavailable $\mathrm{Zn}$ ranged from 0.8

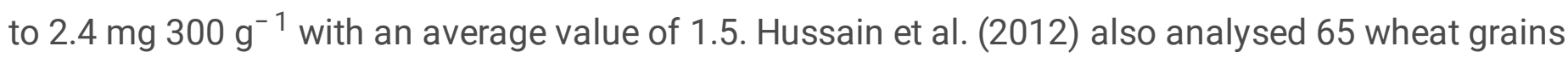
grown in calcareous soils of Pakistan and found that estimated $\mathrm{Zn}$ bioavailability ranged from 1.52 to $2.25 \mathrm{mg} \mathrm{300g}^{-1}$. Thus, the current Kurdistan survey shows that the estimated bioavailable $\mathrm{Zn}$ in wheat grain falls within the range of $\mathrm{Zn}$ bioavailability reported globally for wheat grown in calcareous soils.

On average, about $23.3 \pm 3.48 \%$ of grain $\mathrm{Zn}$ was actually bioavailable. Low bioavailability of $\mathrm{Zn}$ in the wheat was probably due to high PA/Zn molar ratio caused by a high concentration of $\mathrm{P}$ in wheat grains and low $Z n$ concentrations. Li et al. (2015) conducted a two-year field experiment to investigate the effects of $P$ and $Z n$ fertilization on $Z n$ bioavailability in wheat grain. They found that estimated $Z n$ bioavailability in whole grain was greater in the $Z n$-alone treatments than in combined $P+Z n$ treatments.

Table 3

Estimated $\mathrm{Zn}$ bioavailability in $\mathrm{mg} \mathrm{d}^{-1}$ for consumption of $300 \mathrm{~g}$ wheat grain (Eq. 3 ). Samples were collected from ten different locations (Table 1) in Sulaimanyah province.

\begin{tabular}{|lllllllllll|}
\hline Location & SHA & KHO & BAR & HAL & SSQ & SIR & DAR & PIR & KAL & CHA \\
\hline Average & 2.13 & 2.19 & 1.84 & 2.63 & 2.04 & 2.45 & 2.06 & 2.10 & 2.30 & 2.05 \\
\hline SD & 0.06 & 0.11 & 0.08 & 0.05 & 0.04 & 0.10 & 0.07 & 0.10 & 0.06 & 0.08 \\
\hline
\end{tabular}

Figure 5 shows the relationship between estimated bioavailable $\mathrm{Zn}$ and measured PA concentration for all the surveyed wheat grains (whole wheat flour), as determined by the trivariate models used. According to the data and calculations, the estimated bioavailable $\mathrm{Zn}$ decreased by $19.7 \%$, when the concentration of PA intake increased from 885.6 to $3526 \mathrm{mg} \mathrm{300}^{-1}$ in wheat grain (using the full range of measured PA data). Khoshgoftarmanesh et al. (2017) and many other studies have reported that dietary $\mathrm{Zn}$ intake decreases with increasing PA concentration. This present survey indicates that Zn bioavailability in wheat from all regions of Kurdistan, estimated from the trivariate models, is sub-optimum for human health. 


\section{Conclusions}

In approximately $88 \%$ of samples the concentration of $\mathrm{Zn}$ in wheat grain was lower than the recommended value, as expected from the low availability of $\mathrm{Zn}$ in the Kurdistan regional soils. By contrast the $\mathrm{P}$ concentrations were higher than the recommended level in about half of the samples. The composition of the wheat grain, could reasonably be explained as a consequence of large annual applications of $\mathrm{P}$ fertilizer. The PA and PA/Zn molar ratio in wheat grain samples were in the range reported globally. However, the bioavailability to human populations of $Z n$ in wheat grain was low due to high PA concentrations and PA/Zn molar ratios. Results of this survey suggest that foliar application of $\mathrm{Zn}$ in wheat farms could have a significant positive effect on cereal-based food quality grown in the calcareous soils of the Kurdistan region. The problem of low $\mathrm{Zn}$ in wheat in the region is not one of yield restriction but rather of human nutrition.

\section{Declarations}

\section{Acknowledgements}

The Kurdistan Region Government (KRG) is thanked for their financial support of MSR during his PhD studies. Dr Saul Vazquez-Reina it thanked for his help with sample analysis by ICP-MS.

Ethical Approval: none required.

Consent to Participate: none required

Consent to Publish: all authors consent to publish

\section{Authors Contributions:}

All authors are agreeing with this publication and the work finalized under their supervision.

1. Muhammed S. Rasheed: He is lecture at Sulaimanyah Polytechnic University, Iraqi Kurdistan and at the same time he works as a researcher and supervision for MSc. Students

2. Scott D. Young: He is associate professor and he was lecture at the University of Nottingham, United Kingdom. Also He supervised many postgraduate students until he retained last year. Still he is work as reviewer and many activities relates to his specialist.

3. Elisabeth H. Bailey: She is associate professor and she is lecture at the University of Nottingham, United Kingdom. Also se supervised many postgraduate students and still has many postgraduate students. Still she is work as reviewer and many activities relates to here specialist.

Competing Interests: none

Availability of data and materials: only available in electronic appendices or by personal contact with the senior author. 


\section{References}

1. Akram, M. A., Depar, N., and Memon, M. Y. (2017). Synergistic use of nitrogen and zinc to bio-fortify zinc in wheat grains. Eurasian Journal of Soil Science (Ejss) 6, 319-326.

2. Alam, S., M. , and Azam Shah, S. (2002). Phosphorus Uptake and yield of Wheat as Influenced by Intergrated Use of Phopshatic fertilizers Pak. J. Agri. sa 39, 265-268.

3. Bouis, H. E., Hotz, C., McClafferty, B., Meenakshi, J. V., and Pfeiffer, W. H. (2011). Biofortification: A new tool to reduce micronutrient malnutrition. Food and Nutrition Bulletin 32, 31-40.

4. Cakmak, I. (2008). Enrichment of cereal grains with zinc: Agronomic or genetic biofortification? Plant and Soil 302, 1-17.

5. Cakmak, I., and Kutman, U. B. (2017). Agronomic biofortification of cereals with zinc: a review. European Journal of Soil Science.

6. Chen, X. P., Zhang, Y. Q., Tong, Y. P., Xue, Y. F., Liu, D. Y., Zhang, W., Deng, Y., Meng, Q. F., Yue, S. C., Yan, P., Cui, Z. L., Shi, X. J., Guo, S. W., Sun, Y. X., Ye, Y. L., Wang, Z. H., Jia, L. L., Ma, W. Q., He, M. R., Zhang, X. Y., Kou, C. L., Li, Y. T., Tan, D. S., Cakmak, I., Zhang, F. S., and Zou, C. Q. (2017). Harvesting more grain zinc of wheat for human health. Sci Rep 7, 7016.

7. Duffner, A., Hoffland, E., and Temminghoff, E. J. M. (2012). Bioavailability of zinc and phosphorus in calcareous soils as affected by citrate exudation. Plant and Soil 361, 165-175.

8. Erdal, I., Yilmaz, A., Taban, S., Eker, S., Torun, B., and Cakmak, I. (2002). PHYTIC ACID AND PHOSPHORUS CONCENTRATIONS IN SEEDS OF WHEAT CULTIVARS GROWN WITH AND WITHOUT ZINC FERTILIZATION. Journal of Plant Nutrition 25, 113-127.

9. Fageria, V. D. (2001). Nutrient Interactions in Crop Plants. Journal of Plant Nutrition 24, 1269-1290.

10. Gabaza, M., Shumoy, H., Muchuweti, M., Vandamme, P., and Raes, K. (2018). Iron and zinc bioaccessibility of fermented maize, sorghum and millets from five locations in Zimbabwe. Food Research International 103, 361-370.

11. Guttieri, M. J., Baenziger, P. S., Frels, K., Carver, B., Arnall, B., Wang, S., Akhunov, E., and Waters, B. M. (2015). Prospects for Selecting Wheat with Increased Zinc and Decreased Cadmium Concentration in Grain. Crop Science 55.

12. Hussain, S., Maqsood, M., A., Renge, Z., Aziz, T., and Abid, M. (2013). Estimated Zinc Bioavailability in Milling Fractions of Biofortified Wheat Grains and in Flours of Different Extraction Rates. International journal of Agricultur and Biology 15, 921-926.

13. Hussain, S., Maqsood, M., and Miller, L. (2012). Bioavailable zinc in grains of bread wheat varieties of Pakistan. Cereal Research Communications 40, 62-73.

14. Karami, M., Afyuni, M., Khoshgoftarmanesh, A. H., Papritz, A., and Schulin, R. (2009). Grain zinc, iron, and copper concentrations of wheat grown in central iran and their relationships with soil and climate variables. J Agric Food Chem 57, 10876-82.

15. Khoshgoftarmanesh, A. H., Norouzi, M., Afyuni, M., and Schulin, R. (2017). Zinc biofortification of wheat through preceding crop residue incorporation into the soil. European Journal of Agronomy 89, 
131-139.

16. Li, B.-Y., Huang, S.-M., Wei, M.-B., Zhang, H. L., Shen, A. L., Xu, J.-M., and Ruan, X.-L. (2010). Dynamics of Soil and Grain Micronutrients as Affected by Long-Term Fertilization in an Aquic Inceptisol. Pedosphere 20, 725-735.

17. Li, M., Wang, S., Tian, X., Zhao, J., Li, H., Guo, C., Chen, Y., and Zhao, A. (2015). Zn distribution and bioavailability in whole grain and grain fractions of winter wheat as affected by applications of soil $\mathrm{N}$ and foliar Zn combined with N or P. Journal of Cereal Science 61, 26-32.

18. Liu, H., Wang, Z. H., Li, F., Li, K., Yang, N., Yang, Y., Huang, D., Liang, D., Zhao, H., Mao, H., Liu, J., and Qiu, W. (2014). Grain iron and zinc concentrations of wheat and their relationships to yield in major wheat production areas in China. Field Crops Research 156, 151-160.

19. Magallanes-Lopez, A. M., Hernandez-Espinosa, N., Velu, G., Posadas-Romano, G., Ordonez-Villegas, V. M. G., Crossa, J., Ammar, K., and Guzman, C. (2017). Variability in iron, zinc and phytic acid content in a worldwide collection of commercial durum wheat cultivars and the effect of reduced irrigation on these traits. Food Chem 237, 499-505.

20. Maqsood, M. A., Hussain, S., Naeem, M. A., Ahmad, M., Aziz, T., Raza, H. M., Kanwal, S., and Hussain, M. (2014). ZINC INDEXING IN WHEAT GRAINS AND ASSOCIATED SOILS OF SOUTHERN PUNJAB. Pak. J. Agri. Sci. 51, 1-8.

21. Mazid, A. (2015). Status of Wheat Production in Kurdistan Region of Iraq: Results of Baseline Survey. Japan International Cooperation Agency (JICA) and International Center for Agricultural Research in Dry Area (ICARDA).

22. Mousavi, S. R., and Galavi, M. (2012). The interaction of zinc with other elements in plants: A review. International Journal of Agriculture and Crop Sciences 4, 1881-1884.

23. Nikolic, M., Nikolic, N., Kostic, L., Pavlovic, J., Bosnic, P., Stevic, N., Savic, J., and Hristov, N. (2016). The assessment of soil availability and wheat grain status of zinc and iron in Serbia: Implications for human nutrition. Sci Total Environ 553, 141-148.

24. Poblaciones, M. J., and Rengel, Z. (2016). Soil and foliar zinc biofortification in field pea (Pisum sativum L.): Grain accumulation and bioavailability in raw and cooked grains. Food Chem 212, 42733.

25. Svecnjaka, Z., jenel, M., Bujana, M., Vitalib, D., and Dragojevicb, I., V. (2013). Trace element concentrations in the grain of wheat cultivars as affected by nitrogen fertilization. AGRICULTURAL AND FOOD SCIENCE 23, 445-451.

26. Tavajjoh, M., Yasrebi, J., Karimian, N., and Olama, V. (2011). Phytic Acid Concentration and Phytic Acid: Zinc Molar Ratio in Wheat Cultivars and Bread Flours, Fars Province, Iran. J. Agr. Sci. Tech 13, 743-755.

27. Wang, S., Wang, Z., Gao, Y., Liu, L., Yu, R., Jin, J., Luo, L., Hui, X., Li, F., and Li, M. (2017). EDTA alone enhanced soil zinc availability and winter wheat grain Zn concentration on calcareous soil. Environmental and Experimental Botany 141, 19-27. 
28. Wu, P., Cui, P. X., Fang, G. D., Wang, Y., Wang, S. Q., Zhou, D. M., Zhang, W., and Wang, Y. J. (2017). Biochar decreased the bioavailability of $\mathrm{Zn}$ to rice and wheat grains: Insights from microscopic to macroscopic scales. Sci Total Environ 621, 160-167.

29. Zhang, Y., Shi, R., Rezaul, K. M., Zhang, F., and Zou, C. (2010). Iron and zinc concentrations in grain and flour of winter wheat as affected by foliar application. J Agric Food Chem 58, 12268-74.

30. Ziadi, N., Whalen, J. K., Messiga, A. J., and Morel, C. (2013). Assessment and Modeling of Soil Available Phosphorus in Sustainable Cropping Systems. pp. 85-126.

\section{Figures}

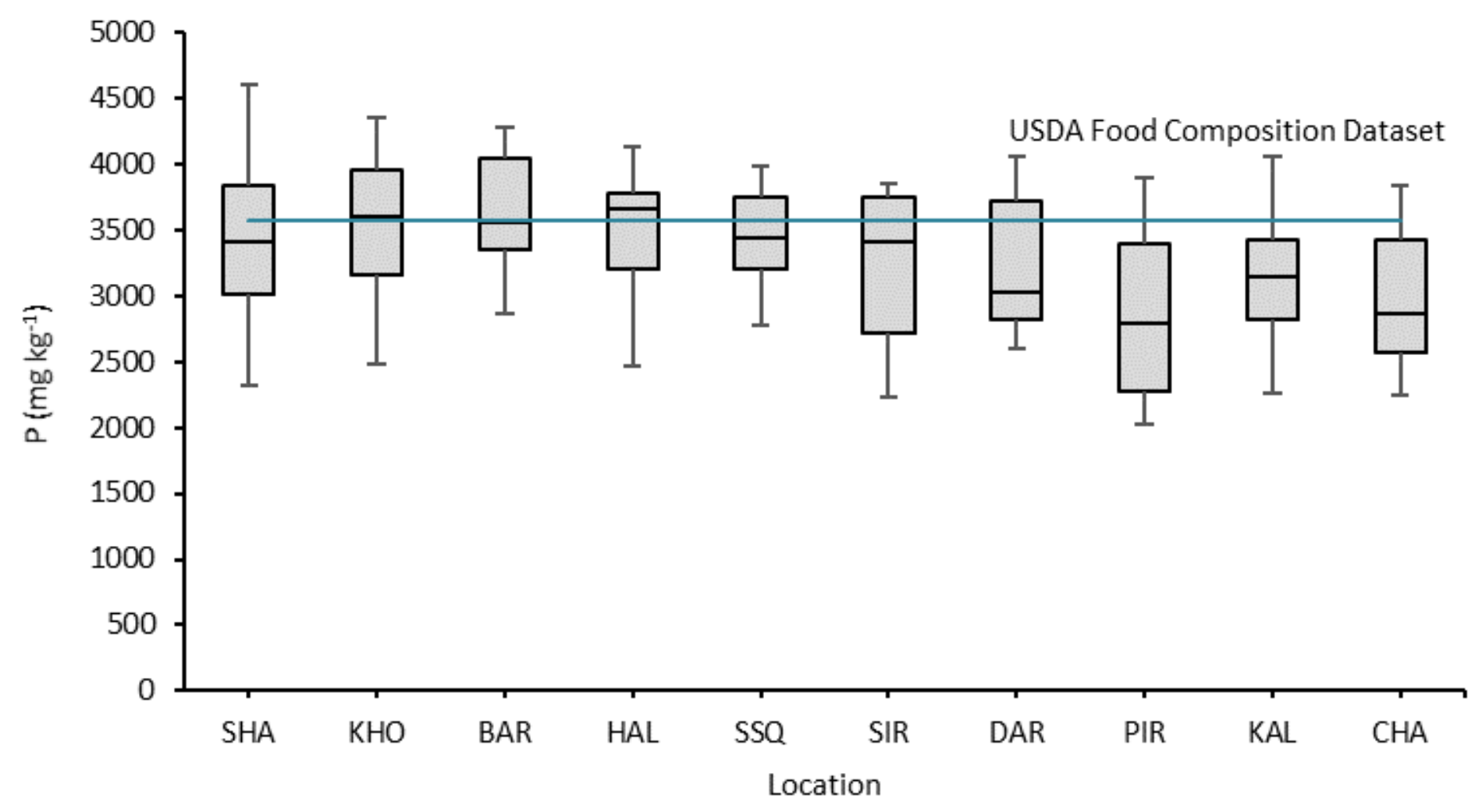

\section{Figure 1}

Concentration of phosphorus in wheat grain samples $(n=120)$ collected at ten locations (Table 1$)$ in Sulaimanyah province, Iraq. 


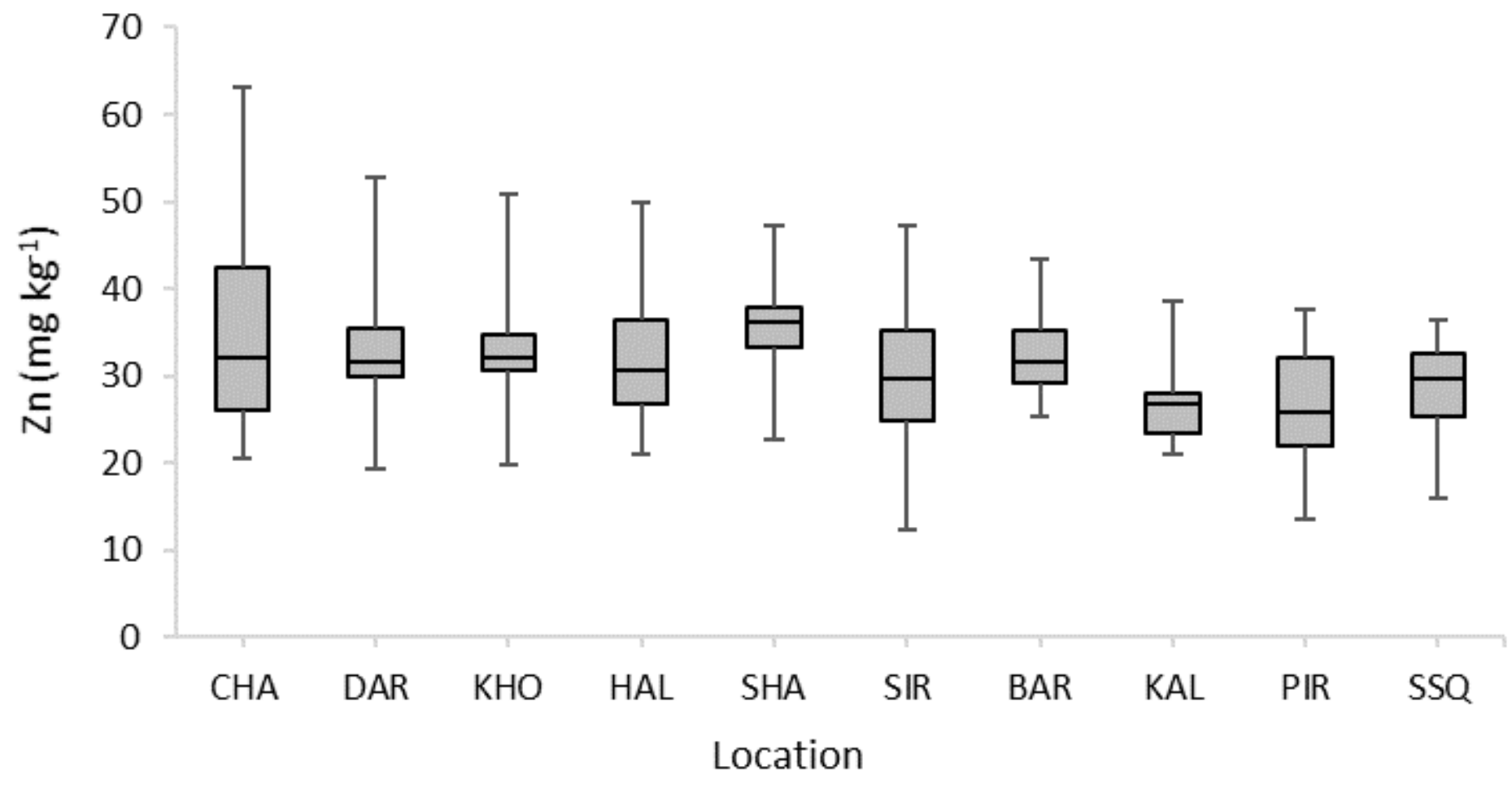

Figure 2

The concentrations of $Z n$ in wheat grain samples $(n=120)$ collected at ten different locations in Sulaimanyah province, Iraq.

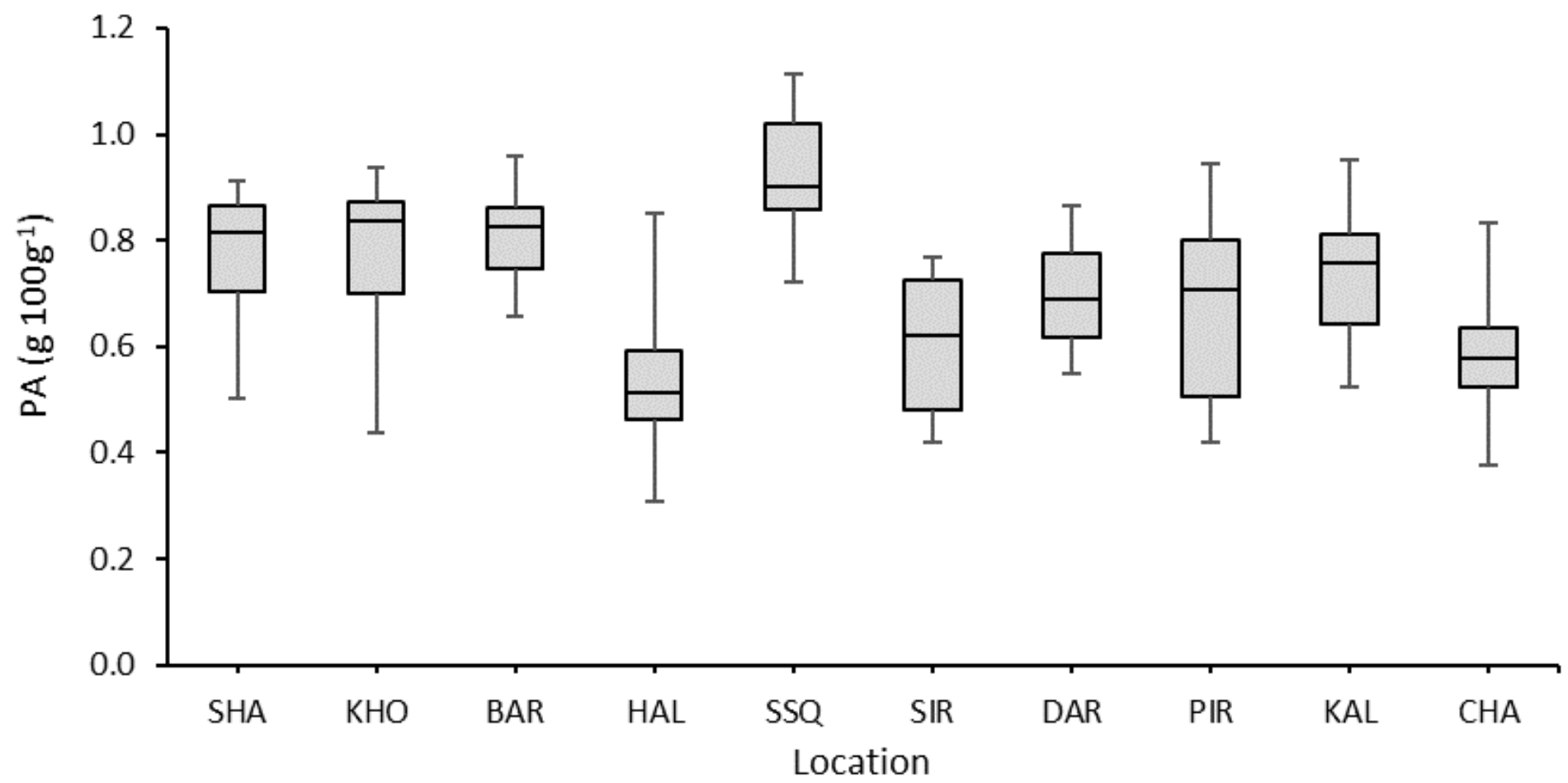

Figure 3 
Range of Phytic acid (PA) concentrations in wheat grain samples $(n=120)$, collected from ten different locations in Sulaimanyah province, Kurdistan region, Iraq.

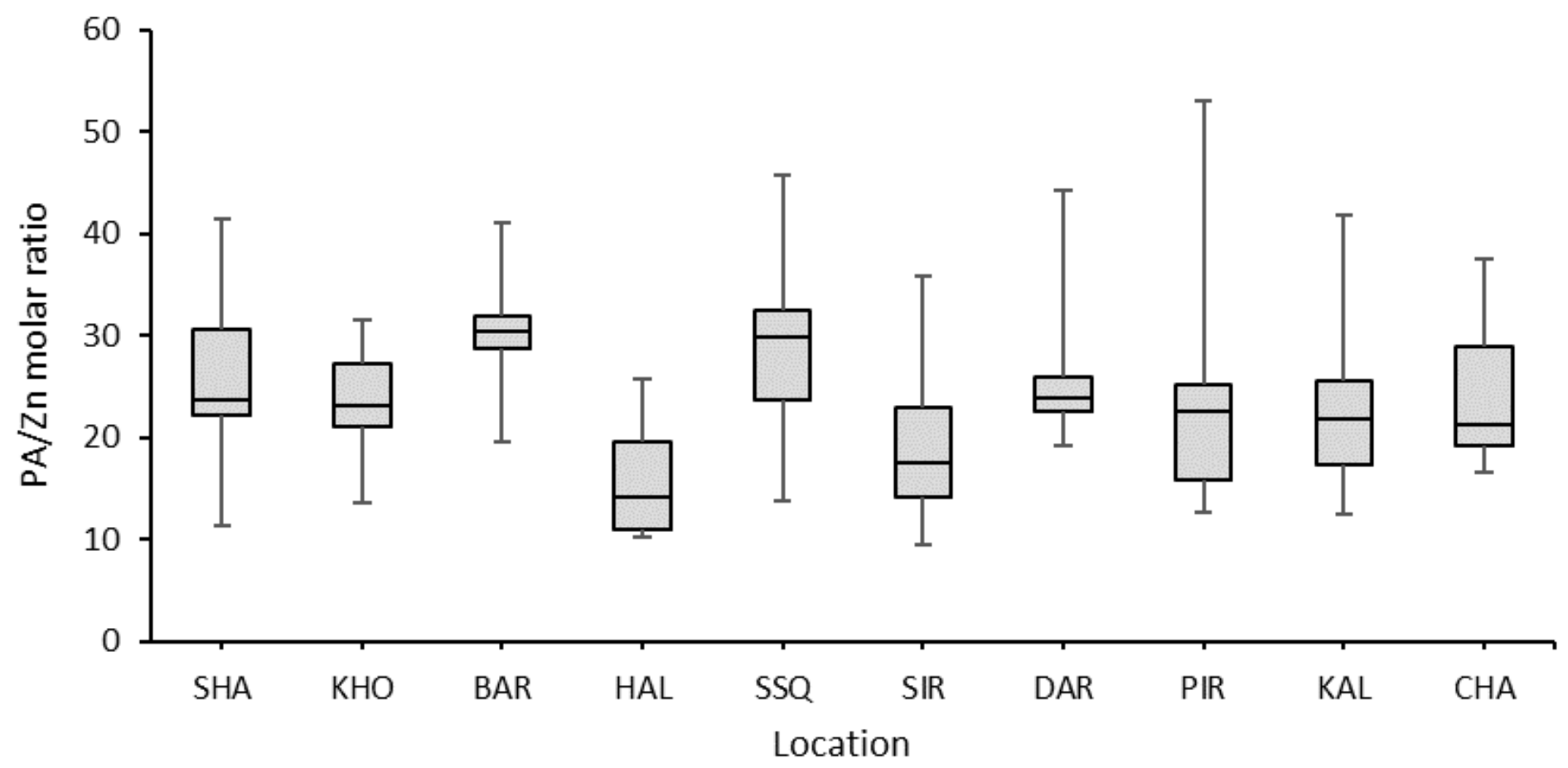

Figure 4

Phytic acid to $Z n$ molar ratio in wheat grain samples $(n=120)$, collected at ten different locations in Sulaimanyah province, Kurdistan region, Iraq.

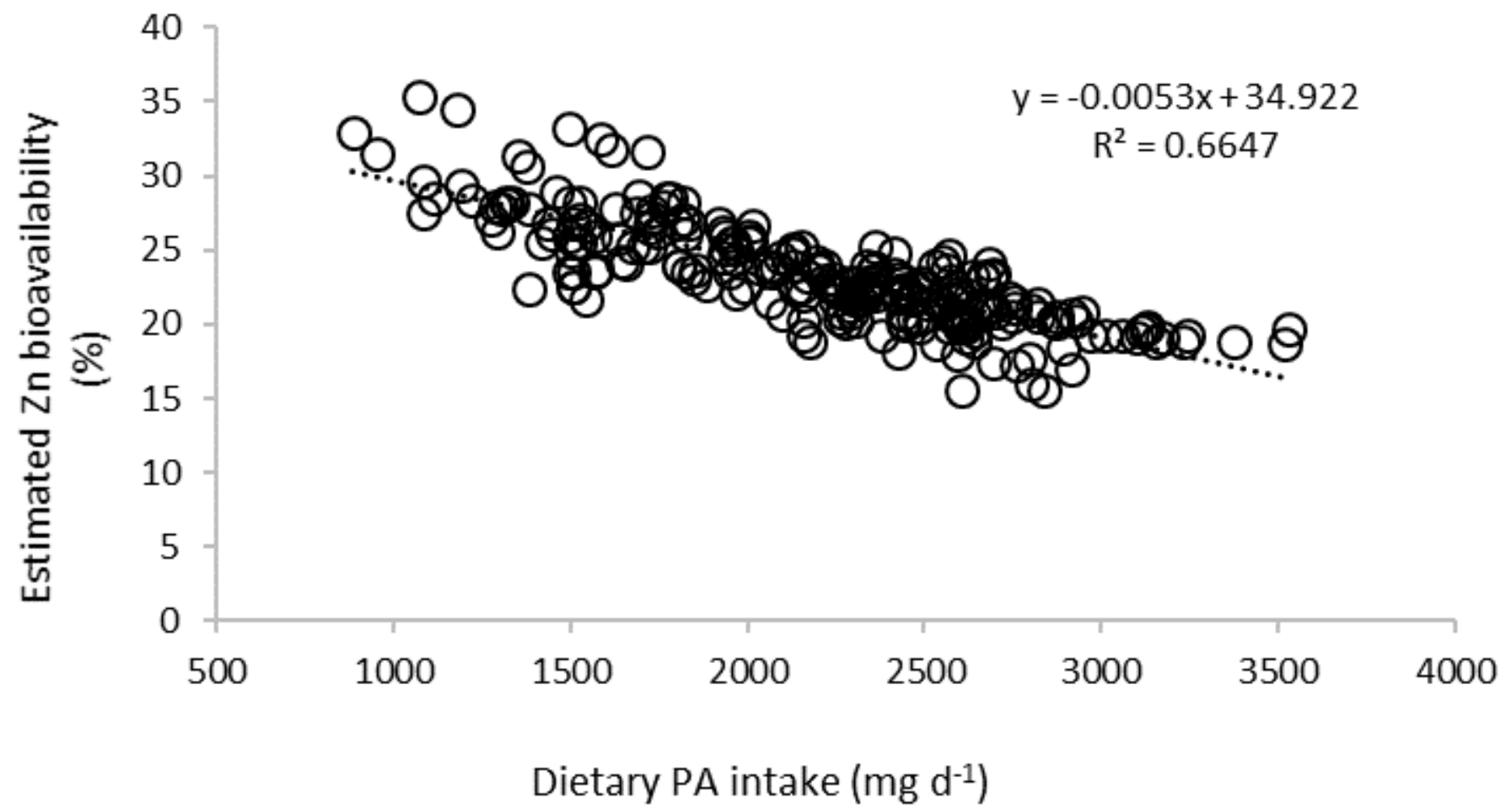




\section{Figure 5}

Relationship between estimated Zn bioavailability (\%) and PA intake from consumption of $300 \mathrm{~g}$ day- 1 of wheat grain. Samples were collected from ten different locations in Sulaimanyah province. 